\title{
Blumenberg's rethoric as the art of delaying
}

\section{A retórica em Blumenberg como a arte do atraso}

Prof. Dr. César González-Cantón

cgcanton@gmail.com

CUNEF - Universidad Complutense de Madrid

In this paper, I attempt to underline the ontological role of rethoric in Blumenberg's philosophic proposal by examining one of the aspects of human temporality: that of human being's neccessity of 'taking their own time'. I trace back this 'need for delaying', structural to human beings, to its anthropological roots in instinct reduction, while attempting at the same time to highlight the relation between this anthropological level of biological 'poverty' and the ontological one of 'metaphysisches Skeptizismus'.

KEY-WORDS Absolutismus der Wirklichkeit; Instinktreduktion; Rethoric

Neste artigo sublinho o papel ontológico da retórica na proposta filosófica de Blumenberg, examinando um dos aspectos da temporalidade humana, a saber: que o ser do homem necessita "tomar o seu próprio tempo". Eu restituo esta "necessidade de atraso" estrutural do ser do homem à sua determnação antropológica de redução do instinto, enquanto tento, ao mesmo tempo, evidenciar a relação entre este nível antropológico de "pobreza" biológica e o ontológico que é o de um "ceticismo metafísico" ("metaphysisches Skeptizismus").

PALAVRAS-CHAVE Absolutismo da realidade; redução do instinto; retórica 
In its effort to understanding themselves and the whole of reality, human beings face a set of "fundamental questions (Grundfragen)" (BLUMENBERG, 1947, p. 5) posed by the fact of existence, i.e., what's the world? where do we come from? why are we here? why is there anything rather than nothing? what's the sense in dying? It is easy to see that being able to answer these questions implies the possession of knowledge characterized by its comprehensiveness and totality. The activity in which such a knowledge takes place has been called since the beginning of philosophizing theory. In the Platonic-Aristotelian tradition, the fulfillment of human life (happiness) is contingent upon this knowledge and, from this perspective, happiness can be understood as reality 'sending' to human beings the answers to these questions. In the experience of happiness following this knowledge it is perceived that reality 'cares for' human beings, i.e., that the world makes sense. Since, in Blumenberg's view, an infinite time would be required to gain such a knowledge, ${ }^{1}$ to attribute sense to reality implies that the cognoscenti are somewhat supposed to live forever and have since ever existed. In other words, the congruence between world-time and lifetime. ${ }^{2}$

The history of thinking has been full of conceptual propositions about the details of this understanding of human beings and reality. All of them, says Blumenberg, boil down to the notion of cosmos, whose exemplary representation was coined in the Ancient Greece by Plato. Suming it up, cosmos means: reality cares for human being.

On the contrary, Blumenberg denies the possibility of finding these answers. Reality does not take care of human beings. It is not possible to take charge of the totality of reality and of one's own existence. It is what Blumenberg terms the "absolutism of reality (Absolutismus der Wirklichkeit)": just as a person is defenceless in front of an absolutist governor, so human beings cannot "control the conditions of their own existence" (BLUMENBERG, 1996, p.10). Which means, above all, when they are born and when they die, because we said that for reality to make sense people should live both since ever and forever. Reality has no sense because we die. Moving himself within a sort of 'negative' platonic framework, the quest for happiness becomes rather a flight from pain.

Not being able to access to the whole of reality is the essence of what Blumenberg calls historicity, finitude or contingence. Things are contingent because they get lost in the current of time and they get irreversibly lost because we are born 'too late' or pass away 'too soon'.

1Cf. BLUMENBERG, 1989, p. 176.

2 This is the title of one of the most famous Blumenberg's books: Lebenszeit und Weltzeit (Frankfurt am Main: Suhrkamp, 1986). 
Blumenberg's position can be described as "ontological skepticism (metaphysisches Skeptizismus)", that would differ from 'rational' skepticism as this can be found in some philosophical systems before him. ${ }^{3}$ The latter certainly states the weakness of our knowledge, but keeps on running along the coordinates established by Plato, taking a basic security in our relationship to reality for grantedthe Being, be it either spiritual or material, one way or the other, cares for man. However, the former declares a radical hostility between human beings and reality.

This ontological deficiency of human beings is the ratio essendi of their anthropological 'poverty' Owhich functions in turn as ratio cognoscendi of the former. Anthropological poverty is the way Blumenberg present the idea of man as an animal suffering from lack of instincts (Instinktreduktion). ${ }^{4}$ As 20th-century German philosophical anthropology explains, this means a huge disadvantage in respect to the other animals. ${ }^{5}$ The reason is that instincts help animals to survive by reducing environmental uncertainty. ${ }^{6} \mathrm{An}$ instinct can be described as an inborn configuration of animal tendencies resulting from an evolutive specialization, which allows an automatic response as triggered by specific estimuli.? Thanks to them, an animal always knows what to do and how to do it. Quite not the same as human beings, whose evolutionary development as a species has suffered a "retardation". ${ }^{8}$ Man is, with Herder's term, a Mängelwesen, ${ }^{9}$ a creature plagued with deficiencies. In substitution of such accurate instruments in the struggle to survive emerges in man rationality and, consequently, culture..$^{10}$

One aspect of the ontological poverty of man, made possible by instinct reduction, is its "openness" (with the term inherited from Max Scheler ${ }^{11}$ ). Human nature does not tend to a goal given by reality, it is comprised mainly of possibilities rather than facts. Man is a "being of possibilities (Möglichkeitswesen)", ${ }^{12}$ burdened with the task of 'creating' himself and its destiny.

3 Cf. BLUMENBERG, 1985, p. 218-19.

4Cf. GEHLEN, 1962, p. 99-100; ALSBERG, 1922, p. 99.

5Cfr. BLUMENBERG, 1989, p. 811.

6Cfr. BLUMENBERG, 1989, p. 812; GEHLEN, 1962, p. 21; ALSBERG, 1922, p. 482.

7Cf. UEXKÜLL,1920, p. 116-7.

8BOLK, 1926, p. 469-70.

9HERDER, 1772.

10Cf. GEHLEN, 1962, p. 38; ALSBERG, 1922, p.44.

11 “Offenheit": SCHELER, M. 1954.

12BLUMENBERG. 1997, p. 212. 
Yet the novelty of Blumenberg's proposition lies not only in his understanding of the radical finitude of human existence described hitherto. He combines it with the idea that human beings are always trying to avoid the experience of contingence. Thus, human existence consists for Blumenberg in a dialectical movement between two equally dominating ontological poles: the awareness of contingence (Inständigkeit) and the attempt to silence it (Gegenständigkeit), ${ }^{13}$ that is, to live "as though" (alsob) $)^{14}$ the world had sense i.e. we were immortals. Cosmos is false but unavoidable. Both mankind's and personal history move, like a pendulum, between these two poles. ${ }^{15}$

Blumenberg attributes consequently a double functionality to human rationality. On the one hand, reason has an inherent inclination to reveal the finite nature of existence, which means: there's no reason for existence... This is the way in which Blumenberg understands the 'absolutist reason' highlighted by some contemporary thinkers. Blumenberg calls the output of this reason truth. On the other hand, reason also tends fundamentally to cover finitude. It is the logic of life, that pursues its "own preservation (Selbsterhaltung)"16 above all: ... but I exist. This aspect of reason is seen by Blumenberg as rethorically shaped. Its byproduct is sense. From the point of view of each type of reason, the opposite pole suffers from irrationality.

Each one of both reason's aspects can take up the form of mythical, scientific or philosophical knowledge. So, opposition between these two different aspects of reason is not contingent on what concrete form it takes, but on the function it develops, i.e., uncovering or covering finitude of human existence.

\section{Rethoric as the art of delaying}

Because of lack of competent means for survival, human beings are animals that have to think twice before coming into contact with reality. Human beings are characterized by what Blumenberg calls a structural 'perplexity'.

13Cf. BLUMENBERG, 1950, p. 201.

14BLUMENBERG, 1987, p. 450.

15 In this way does Blumenberg reinterprets the heideggerian "ontological movement (ontologische Bewegung)" (1950, p. 201; Cf. HEIDEGGER, 1941, §40, 189.). Cf. also BLUMENBERG, 1989 , p. $799 ; 1987$, p. 360 . A sound introduction to this point can be found in DIERSE, 1995, p. 121-129.

16BLUMENBERG, 1960, p. 108-9. Taking into account what it has been said so far, it is clear that the notion of self-preservation extends to biology, personal life and history of civilizations. Cf. also: EBELING, 1976, p. 10. 
This aspect is to be discussed in the following pages under the title of rhetoric as the art of delaying. In so doing, some pheno ena that imply an hesitation in getting to the point (as when we complain about someone who is beating about the bush, or the Ciceronian rethorical devise of circumstantia, or the platonic understanding of rhetoric as art of appearances), are vested with an anthropological and even ontological role. We examine also here the issue of rationality of rhetoric and its ethical consequences.

At the ontological level, to counteract the pressure of reality man places a symbolic world. In relation to our discussion, "lacking definitive evidence"17 in our relation to the world justifies a delaying in our approach to it until we had ideally gained an "understanding (Verständnis)". ${ }^{18}$ However, since that is not possible due to the radical closure of reality, being human means to keep distance from reality in a structural fashion. It could be said: man is an indirect being, a being for whom "detour" 19 is a structural feature. This makes it deserve the name of "hesitant being (zögerndes Wesen)"20: human being's existential structure requires of it 'to take her time' before acting.

Rhetoric can then be understood as human life itself as interposing procedures between human being and reality to avoid dealing directly with it: "circumstantiality (Umständlichkeit)", ${ }^{21}$ the ontologization of Cicero's circumstantia. ${ }^{22}$ An example of this art of delaying are Greek myths. Myth establishes a daedal set of rules and procedures to manage the relation among gods, and between them and mortals; by means of that, what myth is really intending to do is having divine, arbitrary, huge power (i. e. absolute power) contained within certain boundaries. ${ }^{23}$

The basic relation form between human life and reality is therefore - with a term coined by Gehlen. ${ }^{24} \mathrm{O}$ "Entlastung", ${ }^{25}$ discharge of the burden of reality: "substitution of absolutism of reality" ${ }^{26}$ for a world of appearance. This is an ac-

17 Blumenberg, 1987, p. 441.

18 Blumenberg, 1987, p. 447.

19 Blumenberg, 1987, p. 438; BLUMENBERG, 1998.

20 Blumenberg, 1997, p. 487.

21 Blumenberg, 1996, p. 159-60; 1998.

22 CICERO, 2006, I.VIII; Cf. ACCARINO, 1999, p.216, n. 36.

23 For example, Blumenberg considers politeism as a "technique of weakening (Technik der Schwächung)", 1996, p.142.

24GEHLEN, 1962, p. 26.

25 BLUMENBERG, 1989, p. 25.

26BLUMENBERG, 1989, p. 71. 
curate description of Ca sirer's understanding of symbolic expression: "What" comes to man as impression "of something alien and inaccesible" is given back to the world as "sensuously tangible" expression". A symbol or metaphor is, in its Aristotelian sense, something that stands for another thing. ${ }^{28}$ This can be see both in Aristotle's definition of metaphor ${ }^{29}$ and in the etymology of both words,${ }^{30}$ and it is assumed by Blumenberg's definitions of metaphor as a "heterogeneous element that refers to another context", ${ }^{31}$ or something which "displays something that it is not present". ${ }^{32}$ Examples of metaphors for Blumenberg can be that of workclock for the universeOmetaphor invented by Nicolas of Oresme ${ }^{33}$ Oin the beginning of Modernity, or that of Balint's "condensator" as representantion of human psyche. ${ }^{34}$

It is clear that, from this viewpoint, the 'for'-element of the definition of symbol does not point to a possible comprehension of the reality for the metaphor stands. It is the 'stand'-element that is empashized: symbol is, with Aristotle, about "set[ting] things before the eyes", 35 but not in order to help us accept the truth but rather to place a front to prevent us from seeing it. While metaphors are for Aristotle just a resort at hand as it is difficult for an orator to find real life examples, ${ }^{36}$ Blumenberg regards it as the condensation of everything we have said so far. The activity of introducing order in reality at the anthropologi-

27 BLUMENBERG, 1987, p. 438. In Stoellger's opinion, this situates Blumenberg in the Vico-tradition: STOELLGER, 2000, $102 \mathrm{fw}$. Vico is the first author to make a process of construction of metaphors into a "model of adaptation of human behaviour to changing environment": FELLMAN, 1976, 169 fw.

28 Blumenberg hardly distinguishes between metaphor or symbol, rather he considers them as quite equivalent regarding their ability to "represent (Repräsentanz)" (BLUMENBERG, 1997, p. 420); the only difference established by Blumenberg between them is that symbol is what a metaphor becomes when performing its outmost in the substitution of unavailable for available (BLUMENBERG, 1979, p. 96). As Stoellger states correctly, Blumenberg does not take part in the contemporary debate about the symbol theory (STOELLGER, 2000, p. 180).

29 "Metaphor by analogy means this: when B is to A as D is to C, then instead of B the poet will say D and B instead of D. And sometimes they add that to which the term supplanted by the metaphor is relative". (ARISTOTELES, 1932, 1457b, p. 18-20).

$30 \mu \varepsilon \tau \alpha \varphi \circ \rho \alpha$ (from $\mu \varepsilon \tau \alpha$, "change" as verb particle; "between" as adverb; and $\varphi \varepsilon ́ \rho \omega$ cad, "to bring") and $\sigma 0 ́ \mu \beta 0 \lambda o v$ (from , "with"; and -ballein "to put together"); it's well-known that

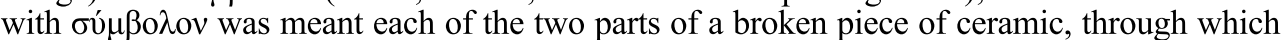
someone's identity could be certified: a short of credential.

31 BLUMENBERG, 1979, p. 98.

32 BLUMENBERG, 1989, p. 26.

33 BLUMENBERG, 1970, p. 340.

34BLUMENBERG, 1998, p. 86.

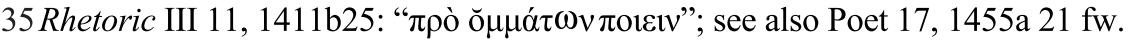

36 See Rhetoric II 20 1, 1393b 5-10. 
cal level is at the same time an ontological process of creation of reality, both external and internal. It's not that human beings create 'the' reality, but surely they create ' $a$ ' reality where they live.

Therefore, the symbolic world would be what we need to busy ourselves with in order to avoid the awareness of death. This is task of rhetoric defined as "art of appearance (Kunst des Scheins)". ${ }^{37}$ Plato's derogatory statement about the rhetorician as being a "conjurer", ${ }^{38}$ turns out to receive a positive ontological significance: rhetoric engages us with its verbal tricks, making appear and disappear a linguistic reality where there is literally nothing. ${ }^{39}$ Language can be regarded, in a Freudian sense, as the 'de-realizator' per excellence. Rhetoric is also then an art of illusionism.

From an anthropological point of view, loss of instincts is like a short circuit in the system stimulus-reaction; in other words, it means the absence of an immediate and automatic reaction to stimulus. This means at least two different problems that human beings must confront.

On the one hand, man faces situations of perplexity or of danger for which they are not biologically equipped. ${ }^{40}$ To them human beings respond not in a physical way, like animals, but in a rhetorical one. ${ }^{41}$ For example, starting a fight can be substituted for a slight raise of the eyebrow with similar results. Human beings do not know (or want) what to do in front of reality urgent requirements, and therefore it does what it can: to do as though it did something. Periphrasizing the sentence attributed to Aristotle, "the tought of fire does not burn", it can be said that the action of symbolizing is not real so far it has no real - physical - impact; but it is on the contrary a 'real' action so far it helps man to survive. The process of "substituting physical accomplishments for verbal [i.e. symbolic] ones is an anthropological "radical"", 42

On the other hand, instinct reduction causes human beings to be deprived of regulating and channeling means for their impulses too, that become exuberant and disorientated. Thus the stimuli overaboundance coming along with instinct reduction is matched by an "impulsive overaboundance". That explains

37BLUMENBERG, 1987, p. 430.

38 “Ө $\theta v \mu \alpha \tau о \pi о \mathrm{\omega v",} \mathrm{Sophist} 235 \mathrm{~b} 3$.

39Cf. BLUMENBERG, 2000, p. 54.

40BLUMENBERG, 1968, p. 137.

41 At least so long as they are allowed to postpone it. Cf. BLUMENBERG, 1987b, p. 13.

42 BLUMENBERG, 1987a, p. 438. Probably these ideas were taken from Plessner, "Homo absconditus", p. 75. 
the common experience of being seized by a fit of passion, which may bring us to lately regrettable decisions. To avoid it human being builts delaying mechanisms in its behavior, both at individual (to give a sober second thought) and institutional levels (some authors interpret in this way the institutional division, in congress and senate, of political choice-making process ${ }^{43}$ ).

Another expression of art of delaying is that human capacity for taking one thing for another is true also from a reverse standpoint: the capability of "delegation (Delegation)", ${ }^{44}$ so that "we need not do or know by ourselves everything that is necessary for self-preservation". ${ }^{45}$ In the pressure of rhetorical situation, to make others make what oneself should (they standing for us) is another means of not having to confront reality.

What is rational in the art of delaying is that it corresponds to the 'logic of life': as we said before, there is no reason for man to exist, yet it exists. It is seen as irrational by both scientific and some philosophical approaches as far as, from the viewpoint of absolutist reason, existence has no reason to exist. For example, while an aspect of technological progress is "concentration of processes [with the] intention of saving time" ${ }^{46}$ so often in human affairs it is more convenient to put off doing something. What is technically possible need not be the most 'timely'. Man is forced to 'procrastrinate' in order to go on being a man. Moreover, technological complexity can nowadays be very much like the original situation of "overabundance of stimuli" 47 that accompanies the lack of instincts. In such open-to-doubt situations, long political/rhetorical digressions can "make uncertain that the shortest line between two points is the human way as well"48.

Blumenberg reinterprets here Husserl's analysis in Die Krisis, upon the irrationality of natural sciences and their technological appendix in the context of the need for a clarifying reflection about both the sense of the world and of human being and its action. ${ }^{49}$ According to Husserl, technology is led by an "active ignorance" $" 50$ (it's enough to know how to use it, not why it works as it does) and needs to be put under the guidance of reason if it has to serve human interests.

43 ELSTER, 1992, p. 35-53.

44BLUMENBERG, 1997, p. 420.

45 BLUMENBERG, 1989, p. 71.

46BLUMENBERG, 1987a, p. $444-45$

47 BLUMENBERG, 1998, p. 111.

48 BLUMENBERG, 1998, p. 122 (emphases added).

49HUSSERL, 1981, p. 14. Cf. Blumenberg, "Lebenswelt", p. 26.

50BLUMENBERG, "Lebenswelt”, p. 33. 
According to Plato, rhetoric gives only an appearance of explanation. Blumenberg's belief is that human life need not investigate its causes, nor with a scientific or philosophical approach, because it would run the risk of discovering it has no sense. Rhetorical metaphors or myths are not used to "replace theory [by giving a 'better' explanation] but to render it unnecessary" 51 by engaging us in a game of apparent explanations. ${ }^{52}$ That is exactly what makes these 'explanations' rational. Prisoners' refusal to leave the platonic cave is not due to their irrationality, but to not wanting to deal directly with reality. ${ }^{53}$

Rhetoric can also take on the form of philosophy as it performs a rhetorical function. That is, philosophy - like Heidegger's existential analysis - can play the game of entertaining us by promising imminent answers to the important questions but actually never getting to them, because such a thing would mean becoming aware that there are no such answers. ${ }^{54}$ Rhetoric disguised as philosophy equates a never-ending rumor superimposing on the terrifying silence of Being. ${ }^{55}$

Without this game of providing apparent answers to the questions posed by reason's inherent tendency to ask for causes, we would get sooner or later to the experience of finitude. From the absolutist reason's point of view, rhetorical speech 'says nothing'; from the rhetoric's side, there's (literally) nothing to say. Reason can accept theoretical requirements to 'cutting the nonsense', 'speaking out plainly'... only at the cost of disappearing itself. Metaphorology, from this viewpoint, by telling the history of metaphors builds up a new history providing an appearance of answers to fundamental questions, but really preventing us from getting to truth. ${ }^{56}$

51 BLUMENBERG, 1989, p. 168. As Gehlen explains (1962, p. 360), in the field of vital knowledge the usual way to elaborate perturbations (for instance a burn) is not to investigate the causes of the event (why fire burns) but rather a shock and the ensuing prevention (not to get too close to the bonfire anymore).

52BLUMENBERG, 1989, p. 164.

53 It's very interesting how Blumenberg describes the situation of someone who leaves the cave: sunlight blinds her and as a result she 'loses' her world: the sun is the truth (finitude), which makes us realize our world is a fake (Cf. 1950, p. 44).

54 BLUMENBERG, 1998. P. 86-7. Memorable description of this point is given by Blumenberg in "Das Sein - ein MacGuffin", Selbstverständnis, p. 157-160.

55 BLUMENBERG, "Weltbilder", p. 69-74.

56 Metaphorology takes, thus, the place of Husserl's phenomenology and its infinite work on the philosophical object (an object that becomes the history of the analytical approaches to it: Cf. LEVINÁS, 1967, p. 174. But Blumenberg subjects this concept to an inversion: infinite work-on is rational not because we get to know better, but because it avoids uncovering. 
Furthermore, the "basic estrangement" 57 between this aspect of reason and life justifies acting "as though (als ob)" $" 58$ absolutist reason's statements were not true. ${ }^{59}$ Rhetoric is, from this point of view, "the art of persuading ourselves to ignore [theory]" in the case it is unbearable for praxis. ${ }^{60}$ As Wardy points out, to enjoy a tragedy one must place herself in disposition to be deceived. ${ }^{61}$

\section{The ethics of delaying}

The consequences of these arguments for ethics are far-reaching. Contrary to human 'openness', for absolutist reason human life is supposed to have a specific target, whose elucidation would be the task of the platonic 'ethical science'. An ethics that, like a platonic one, "takes the evidentness of the good as its point of departure leaves no room for rhetoric as the theory and practice of influencing behavior on the assumption that we do not have access to definitive evidence of the good"62. Platonic man would feel warranted to say to the blumenbergian one: "stop beating about the bush: what you must do is...".

Yet Blumenberg finds this position problematic, even potentially perilous, much more if the philosopher finally becomes king because he would want to impose his idea of happiness to everyone. ${ }^{63}$ Radical absence of a pre-determined telos for human life requires an 'understanding' of a rhetorical kind, that, since a complete determination of human life is not possible, takes detours and persists and is re-elaborated during the whole lifetime. ${ }^{64}$ It would be expected for Blumenberg that tolerance and social cohesion would come out from this.

57BLUMENBERG, 1997, p. 155.

58 BLUMENBERG, 1987a, p. 450.

59 With these reflections Blumenberg pushes forward the husserlian construction of life-world ("Lebenswelt"), that, roughly said, is matched by Husserl to ordinary life and thought as a reserve of sense for human life in front of the abstraction of occidental science. HUSSERL, 1956, p. 232. Cf. BLUMENBERG, 1998, p. 107.

60BLUMENBERG, 1987a, p. 451.

61 WARDY, p. 36.

62 BLUMENBERG, 1987a, p. 432.

63 Cf. BLUMENBERG, 1997, p. 187, p. 76. As Wardy says (p. 76), Plato rejects democracy because he considers that truth does not emerge in the agora, but in the face to face conversation: Socrates affirms that the single witness of the veracity of his reasonings that he admits, is his persuaded interlocutor (Gorgias 474a5-b1).

64BLUMENBERG, Matthäuspassion, p. 96. 
Furthermore, understanding human action's rationality is, from this standpoint, an "introduction to every ethical problem. We should know what we are doing in order to know whether it is what we should be doing". ${ }^{65}$ In this sense, being aware of the twofold form of rationality, the structural lack of resolution of the questions about reality and one's own self, and the rethorical shape of one aspect of rationality allows the rational agent to critically confront social customs and social dilemmas.

65 BLUMENBERG, "Weltbilder", p. 68.

BLUMENBERG, H. An Anthropological Approach to the Contemporary Significance of Rhetoric. In.: After Philosophy? End or Transformation. Kenneth Baynes, James Bohman, and Thomas McCarthy, eds. Robert M. Wallace, trans. Cambridge: The MIT Press, 1987a.

Arbeit am Mythos. Frankfurt am Main:

Suhrkamp, 1996.

Ausblick auf eine Theorie der Unbegrifflichkeit. In.: Schiffbruch mit Zuschauer. Paradigma einer Daseinsmetapher. Frankfurt am Main: Suhrkamp, 1979.

Begriffe in Geschichten. Frankfurt am Main: Suhrkamp, 1998.

. Beiträge zum Problem der Ursprünglichkeit der mittelalterlichscholastischen Ontologie. Kiel: 1947. (Not published dissertation's work).

. Die ontologische Distanz, Eine Untersuchung über die Krisis der Phänomenologie Husserls. Kiel: 1950. Die Verführbarkeit des Philosophen. Frankfurt am Main: Suhrkamp, 2000.

\section{$\{$ Referência Bibliográfica}

. Die Sorge geht über den Fluß. Suhrkamp, Frankfurt am Main 1987b.

. Gerade noch Klassiker. Glossen zu Fontane. München: Hanser, 1998.

Höhlenausgänge. Frankfurt am Main: Suhrkamp, 1989.

Lebensthemen. Aus dem Nachla. Stuttgart: Reclam, 1998, 15 fw.

Lebenszeit und Weltzeit. Frankfurt am Main: Suhrkamp, 1986.

. Paradigmen zu einer Metaphorologie. In.: Archiv für Begriffsgeschichte 6, 1960.

Selbsterhaltung und Beharrung. Zur Konstitution der neuzeitlichen Rationalität. In.: Akademie der Wissenschaften und der Literatur in Mainz. Abhandlungen der geistes- und sozialwissenschaftlichen Klasse 11, 1970.

.The Legitimacy of the Modern Age. Robert Wallace, trans. Cambridge and London: MIT Press, 1985. 
. Vollzähligkeit. Frankfurt am Main: Suhrkamp, 1997.

.Wirklichkeitsbegriff und Staatstheorie. In.:

Schweizer Monatshefte 481968.

.CICERO. Topica. Tobias Reinhardt, ed. New

York: Oxford University Press, 2006.

DIERSE, U. Hans Blumenberg: Die Zweideutigkeit des Menschen. In.: Reports on Philosophy 15, 1995.

EBELING, H. Einleitung: Das neuere Prinzip der Selbsterhaltung und seine Bedeutung für die Theorie der Subjektivität In.: Subjektivität und Selbsterhaltung. Beiträge zur Diagnose der Moderne, Suhrkamp, 1976.

ELSTER, J. Intertemporal choice and political thought. In.: LOEWENSTEIN, G. \&

ELSTER, J. (org.). Choice over time. New York: Russell Sage Foundation, 1992.

FELLMAN, F. Vico-Axiom. Der Mensch macht die Geschichte. Freiburg i. Br, 1976.

GEHLEN, A. Der Mensch, Seine Natur und seine Stellung in der Welt. Athenäum Verlag, 1962.

HEIDEGGER, M. Sein und Zeit. Max Niemeyer. ed., Halle, 1941.

HERDER, J. G. Abhandlung über der Ursprung der Sprache. Berlin: 1772.

HUSSERL. Kant und die Idee der Traszendentalphilosophie. Erste Philosophie (1923/24). Erster Teil: Kritische Ideengeschichte. Husserliana. Gesammelte Werke VII. Rudolf Boehm, ed. Den Haag: Martinus Nijhoff, 1956.

Philosophie als strenge Wissenschaft. Frankfurt am Main: Suhrkamp, 1981.

LEVINÁS, E. En découvrant l'existence avec Husserl et Heidegger. Paris: Vrin, 1967.
SCHELER, M. Vom Wesen der Philosophie und der moralischen Bedingung des philosophischen Erkennens. In. Vom Ewigen im Menschen, Gesammelte Werke vol. 5. Bern: 1954.

STOELLGER, P. Metapher und Lebenswelt: Hans Blumenbergs Metaphorologie als Lebenswelthermeneutik und ihr religionsphänomeno-logischer Horizont. Tübingen: Mohr Siebeck, 2000.

UEXKÜLL, J. Von. Theoretische Biologie. Berlin: Gbr. Paetel: 1920. 